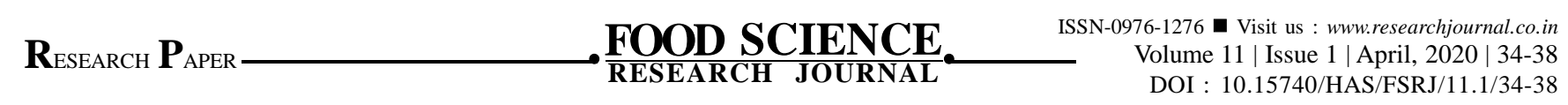

\title{
Development of pearl millet (Pennisetum glaucum) products
}

\begin{abstract}
R.H. Gore, T.N. Khan and J.P. Nerlekar
Pearl millet is rich and inexpensive source of dietary fibre, protein, iron, calcium, minerals, protein, B-vitamins, potassium, phosphorus, magnesium, zinc-copper and manganese. Food based approaches have higher potential for achieving far reaching and long lasting benefits for the control of iron and other micronutrient deficiencies, therefore, there is a need to identify nutrient rich foods that can be produced inexpensively to meet the nutrient requirements for vulnerable groups. Iron content of pearl millet is $8 \mathrm{mg} / 100 \mathrm{~g}$. Thus, utilizing pearl millet four iron rich product were developed namely Pearl pop, Pearl pop chiwada, Pearl pop chikki and Pearl pop namkeen. Developed products were evaluated for acceptability and highly accepted variation was subjected for nutrient analysis.
\end{abstract}

Key Words : Development of iron rich products, Acceptability, Nutrient analysis

How to cite this article : Gore, R.H., Khan, T.N. and Nerlekar, J.P. (2020). Development of pearl millet (Pennisetum glaucum) products. Food Sci. Res. J., 11(1): 34-38, DOI : 10.15740/HAS/FSRJ/11.1/34-38.Copyright@ 2020: Hind Agri-Horticultural Society.

R. H. Gore, Department of Food Science and Nutrition, College of Community Science, Vasantrao Naik Marathwada Krishi Vidyapeeth, Parbhani (M.S.) India

Associate Authors' :

T.N. Khan and J.P. Nerlekar, Department of Food Science and Nutrition, College of Community Science, Vasantrao Naik Marathwada Krishi Vidyapeeth, Parbhani (M.S.) India

Email: k_naheed@rediffmail.com 